\title{
Hector McGillivray, Malraux et la révolte irrationnelle, politique, histoire et culture
}

\section{Emanuele Kanceff}

\section{(2) OpenEdition}

12 Journals

\section{Edizione digitale}

URL: http://journals.openedition.org/studifrancesi/9665

DOI: 10.4000/studifrancesi.9665

ISSN: 2421-5856

\section{Editore}

Rosenberg \& Sellier

\section{Edizione cartacea}

Data di pubblicazione: 1 décembre 2007

Paginazione: 696

ISSN: 0039-2944

\section{Notizia bibliografica digitale}

Emanuele Kanceff, «Hector McGillivray, Malraux et la révolte irrationnelle, politique, histoire et culture», Studi Francesi [Online], 153 (LI | III) | 2007, online dal 30 novembre 2015, consultato il 10 janvier 2021. URL: http://journals.openedition.org/studifrancesi/9665; DOI: https://doi.org/10.4000/studifrancesi. 9665

Questo documento è stato generato automaticamente il 10 janvier 2021.

\section{(c) (1)}

Studi Francesi è distribuita con Licenza Creative Commons Attribuzione - Non commerciale - Non opere derivate 4.0 Internazionale. 


\title{
Hector McGillivray, Malraux et la révolte irrationnelle, politique, histoire et culture
}

\author{
Emanuele Kanceff
}

\section{NOTIZIA}

HECTOR MCGILIVRAY, Malraux et la révolte irrationnelle, politique, histoire et culture, ParisCaen, Lettres Modernes Minard, 2000, pp. 120 (Coll. «Archives des lettres modernes», 279).

1 Segnaliamo questa succinta guida letteraria che era fino a ora sfuggita alla nostra attenzione. L'autore, allievo di Walter Polland (Università di Auckland), caduto anche lui nella pania delle contraddizioni che circondano il celebre scrittore, vuole liberarsene studiando dapprima l'evoluzione della coscienza politica di Malraux, dal riformatore liberale al democratico antifascista al patriota gaullista, il disegno grandioso afro-asiatico, l'antimarxismo, lo scrittore della volontà e del destino. Poi affronta la figura dello scrittore dal punto di vista della cultura e della politica, fino alle ultime conseguenze del marzo '68, crisi di coscienza e coscienza della crisi. La conclusione dell'itinerario critico è la messa in rilievo della "rivolta" che sembra essere l'unica vera costante di questo spirito nel suo confronto indefinito con la Storia, che lo conferma più interessato al combattimento che non alla vittoria. 